\title{
Whitefly population dynamics in okra plantations
}

\author{
Germano Leão Demolin Leite ${ }^{(1)}$, Marcelo Picanço(2), Gulab Newandram Jham(3) \\ and Márcio Dionízio Moreira(2)
}

\begin{abstract}
(1)Universidade Federal de Minas Gerais, Instituto de Ciências Agrárias, Caixa Postal 135, CEP 39404-006 Montes Claros, MG. E-mail: gldleite@ufmg.br (2)Universidade Federal de Viçosa (UFV), Dep. de Biologia animal, CEP 36571-000 Viçosa, MG. E-mail: picanco@mail.ufv.br (3)UFV, Dep. de Química. E-mail: gulab@mail.ufv.br
\end{abstract}

\begin{abstract}
The control of whitefly Bemisia tabaci (Gennadius) biotype B (Hemiptera: Aleyrodidae) on okra (Abelmoschus esculentus L.) consists primarily in the use of insecticides, due to the lack of information on other mortality factors. The objective of this study was to evaluate the spatial and temporal population dynamics of the whitefly B. tabaci biotype B on two successive A. esculentus var. "Santa Cruz" plantations. Leaf chemical composition, leaf nitrogen and potassium contents, trichome density, canopy height, plant age, predators, parasitoids, total rainfall and median temperature were evaluated and their relationships with whitefly on okra were determined. Monthly number estimates of whitefly adults, nymphs (visual inspection) and eggs (magnifying lens) occurred on bottom, middle and apical parts of 30 plants/plantation (one leaf/plant). Plants senescence and natural enemies, mainly Encarsia sp., Chrysoperla spp. and Coccinellidae, were some of the factors that most contributed to whitefly reduction. The second okra plantation, $50 \mathrm{~m}$ apart from the first, was strongly attacked by whitefly, probably because of the insect migration from the first to the second plantation. No significant effects of the plant canopy on whitefly eggs and adults distribution were found. A higher number of whitefly nymphs was found on the medium part than on the bottom part.
\end{abstract}

Index terms: Bemisia tabaci, Abelmoschus esculentus, natural enemies, plant phenology, temperature.

\section{Dinâmica populacional de mosca-branca em quiabo}

Resumo - O controle da mosca-branca Bemisia tabaci (Gennadius) biótipo B (Hemiptera: Aleyrodidae) em quiabeiro (Abelmoschus esculentus L.) consiste principalmente no uso de inseticidas, em virtude da falta de informação sobre outros fatores de mortalidade. O objetivo deste trabalho foi compreender a dinâmica populacional, espacial e temporal da mosca-branca em dois cultivos sucessivos de quiabeiro "Santa Cruz". Avaliaram-se a composição química foliar, os níveis foliares de nitrogênio e de potássio, a densidade de tricomas, a altura de dossel, a idade de planta, predadores, parasitóides, pluviosidade total, temperatura média e suas relações com a mosca-branca em quiabeiro. Estimou-se, mensalmente, o número de adultos e de ninfas (inspeção visual) e de ovos (lentes de aumento) de mosca-branca ocorridos nas folhas (uma folha/planta) localizadas nas partes basal, mediana e apical de 30 plantas/plantação. Os fatores que mais contribuíram com a redução da população mosca-branca foram a senescência de plantas e inimigos naturais, principalmente Encarsia sp., Chrysoperla spp. e Coccinellidae. O segundo cultivo de quiabo, a $50 \mathrm{~m}$ do primeiro, foi altamente atacado pela mosca-branca, provavelmente pela migração dos insetos do primeiro para o segundo cultivo. Não foi detectado efeito significativo do dossel de plantas sobre ovos e adultos. Foi encontrado maior número de ninfas na parte mediana do que na parte basal das plantas.

Termos para indexação: Bemisia tabaci, Abelmoschus esculentus, inimigos naturais, fenologia da planta, temperatura.

\section{Introduction}

Okra, Abelmoschus esculentus L. (Malvaceae), is a tall-growing, warm-season, annual crop cultivated in Brazil, southern USA and the West India for its long, manyseeded pods, used as a vegetable. The whitefly, Bemisia tabaci (Gennadius) biotype B (or B. argentifolii)
(Hemiptera: Aleyrodidae), causes severe damage to okra plants by feeding on sap, secreting honeydew and transmitting virus diseases (Fishpool \& Burban, 1994; Umaharan et al., 1998; Jose \& Usha, 2003). This control consists, primarily, in blanket use of insecticides, due to the lack of information about other mortality factors (Dent, 1995). 
Temperature and rainfall influence the whitefly population dynamics (Horowitz et al., 1984; Horowitz, 1986). Excess of nitrogen (N) and deficiency in potassium $(\mathrm{K})$ can lead to higher attack rate, whereas younger plants are more attacked than older or slow growing plants, as related in Lycopersicon esculentum Mill. by Marschner (1995) and Leite et al. (1998).

Leaf position in the plant canopy and trichomes influences whitefly oviposition rates as well as parasitism, such as observed in L. esculentum (Stansly et al., 1997; Leite et al., 1998) and, therefore, natural enemies could contribute to pest control in several crops (A. esculentus, Brassica oleracea var. acephalata L., Cucumis sativus L., C. melo indorus Naud., Cucurbita pepo L., Citrullus lanatus (Thunb.) Matsum \& Nakai, Gossypium hirsutum L., Ipomoea batatas (L.) Lam., L. esculentum, Phaseolus vulgaris L., Solanum melongena L., and Vigna unguiculata (L.) Walp (Stansly et al., 1997). However, these factors have been poorly studied on okra.

The aim of the present investigation was to evaluate the effect of predators, parasitoids, rainfall, temperature, leaf chemical composition, levels of $\mathrm{N}$ and $\mathrm{K}$, leaf trichome density, height canopy height, plant age and their relationships on whitefly population dynamics.

\section{Material and Methods}

The experiment was carried out in two okra plantations of A. esculentus var. "Santa Cruz" from Guidoval, Minas Gerais, Brazil. Fertilization and cultural practices were used (Filgueira, 2000). The two okra plantations were spaced $50 \mathrm{~m}$, and had gramineae of small height between them; each plantation comprised 3.6 ha with 10,000 plants, $0.30 \mathrm{~m}$ apart on the row and $1.2 \mathrm{~m}$ between rows. The 10 peripheral rows and 40 plants on each end of the row were not considered, leaving a useful area of 2.7 ha, i.e. 30 rows, $176 \mathrm{~m}$ long. The first 16day-old plantation was evaluated from March $1^{\text {st }}$ to June $30^{\text {th }} 1999$, while the second, a 50-day-old plantation, was evaluated from July $1^{\text {st }}$ to November $30^{\text {th }} 1999$. After the final evaluation, the first plantation was eliminated. These plantations were far from other vegetable crops (i.e., B. oleracea var. capitata L., C. sativus, C. pepo, L. esculentum, P. vulgaris, S. melongena) at least $1,000 \mathrm{~m}$.

Monthly number estimates of $B$. tabaci biotype B adults and nymphs (abaxial face), and predators (adults + larvae), both faces, occurred by visual inspection (Horowitz, 1986, 1993) on the bottom, middle and apical parts of 30 plants/plantation (one leaf/plant). B. tabaci biotype B eggs, and their spatial distribution on okra plants were evaluated monthly, with magnifying lens (Farias, 1994). One expanded leaf on each part of the canopy of 30 plants/plantation, one leaf/plant, was collected, sealed in transparent white plastic bags and transported to the laboratory for counting. As far as each sample is concerned the abaxial face, six fields (area of one field: $0.60 \mathrm{~mm}^{2}$ ) in the median part, equidistant between the median vein and the margin, were analyzed. The beating tray method (Miranda et al., 1998) was used monthly to estimate the number of parasitoids present in one leaf from each of 10 plants/plantation. The first expanded leaf/apex of the plant was beaten on a $34 \times 26 \times 5 \mathrm{~cm}$ white tray to collect the insects with an aspirator or tweezer and placed individually in $8 \times 2 \mathrm{~cm}$ glass flasks, containing $70 \%$ ethanol for identification.

One apical leaflet from each part of the canopy of nine plants/plantation was collected, monthly, on three occasions, and placed in white transparent plastic bags, sealed and stored in $70 \%$ ethanol, for analysis. Leaflets were cleared for 2 hours in $10 \% \mathrm{NaOH}$ and 18 hours in sodium hypochlorite $(20 \%)$. After washing and during the dehydration, leaflets were stained for $3 \mathrm{~min}$ in fast green and mounted between slides using Canadian balsam. The number of adaxial and abaxial trichome was counted under a light microscope on the apical leaflet's median part. In each sample, six fields of $0.60 \mathrm{~mm}^{2}$, each between the median vein and the margin were analyzed.

One expanded leaf from the apex of each of 15 plants/ plantation was monthly collected and taken to the laboratory for $\mathrm{N}$ and $\mathrm{K}$ determination. The leaves were placed in Kraft paper bags, dried in a forced air circulation oven at $67^{\circ} \mathrm{C}$ for three days and nitrogen ground in a Wiley mill (20 mesh). Potassium was determined with a flame photometer and analyzed by the Nessler method. Three evaluations, consisting of five leaves in each evaluation, were made for each collection of two plantations.

For gas chromatography/mass spectrometry (GC/MS) analysis, fully expanded apical leaves of 15 plants/ plantation were sampled monthly, placed in plastic bags, sealed for and transported to the laboratory. A 10-g latch was cut with scissors, immersed in $100 \mathrm{~mL}$ of bidistilled hexane for 24 hours, dehydrated with anhydrous $\mathrm{Na}_{2} \mathrm{SO}_{4}$, evaporated to dryness at $30^{\circ} \mathrm{C}$ in a rotatory evaporator, 
sealed in nitrogen and stored in a freezer until being analized.

The hexane extracts were analyzed by an autosampler, Model QP 5000, a computer-based system to accumulate data and a mass spectra database (John Wiley) with 160,000 compounds. The oven was programmed to develop a temperature gradient, from $33^{\circ} \mathrm{C}$ to $80^{\circ} \mathrm{C}$, at $20^{\circ} \mathrm{C} / \mathrm{min}$, and when a higher temperature was achieved, a new gradient from $80^{\circ} \mathrm{C}$ to $250^{\circ} \mathrm{C}$ was carried through at $5^{\circ} \mathrm{C} / \mathrm{min}$. The injector and transfer line temperatures were of $180^{\circ} \mathrm{C}$ and $250^{\circ} \mathrm{C}$, respectively. The split ratio was five, with $\mathrm{He}$ as the carrier gas. All analyses were carried out on a fused capillary column of $30 \mathrm{~m} / 0.25 \mathrm{~mm}$ and film thickness of $0.25 \mu \mathrm{m}$. The ionization voltage was $70 \mathrm{eV}$ and the mass spectrometer scanned between 40-550 amu (atomic mass unit). Retention times for peaks with total ion current (TIC) higher than $4 \times 10^{5}$ ions/sec were recorded with a minimum area for peak integration of $400,000 \mathrm{ions} / \mathrm{sec}$. The compounds were identified using the mass spectral database and only compounds with a similarity index (SI) greater than $83 \%$ were considered as positive identifications. Further identification through standards was not attempted.

Guidoval's climatic data, total rainfall and median temperature (minimum + maximum/2), were read daily from a pluviometer and thermometer, installed in the field at the beginning of the experiment. Canopy height effects on pedators, parasitoids, trichome densities, and B. tabaci population density were virified by variance analysis and the Turkey's multiple range test $(\mathrm{P} \leq 0.05)$. Regression analyses $(\mathrm{P} \leq 0.05)$ were used to evaluate the relationships of predators, parasitoids, total rainfall, median temperature, leaf chemical composition, leaf $\mathrm{N}$ and $\mathrm{K}$ levels, plant age and leaf trichome density with the whitefly number on okra plants.

\section{Results and Discussion}

In the first okra plantation, the whitefly adult population decreased from March to May and increased from May to June, while the number of nymphs peaked in April, and that of eggs, in May (Figure 1). In the second plantation, adult populations peaked in September and nymphs presented two peaks, the first in August and the second in October, the latter with large number of eggs. Median temperature and total rainfall did not correlate with whitefly density.

Peak populations of Encarsia sp. (Hymenoptera: Aphelinidae) were observed in April and September,
Chrysoperla spp. (Neuroptera: Chrysopidae) in June, August and October and ladybirds [Cycloneda sanguinea (L.), Psyllobora lenta (Mulsant) and Sciminus sp. (Coleoptera: Coccinellidae)] in April and October (Figure 1). Correlations were found between Chrysoperla spp., ladybirds, and Encarsia sp. with whitefly nymphs $\left(\mathrm{y}=-0.004+411.11-1482.32 \mathrm{x}^{2}\right.$, $\mathrm{R}^{2}=0.55 ; \mathrm{y}=0.20+0.02 \mathrm{x}, \mathrm{R}^{2}=0.45$; and $\mathrm{y}=2.88+$ $59.90 \mathrm{x}-35.53 \mathrm{x}^{2}, \mathrm{R}^{2}=0.36$, respectively). No correlation was found between Orius sp. (Heteroptera: Anthocoridae) (0.01 $\pm 0.01 /$ leaf), Syrphidae (Diptera) $(0.01 \pm 0.01 /$ leaf $)$ and the spiders $(0.14 \pm 0.04 /$ leaf $)$ Cheiracanthium inclusum (Hentz) (Miturgidae), Dictyna sp. (Dictynidae), Eustala sp. (Araneidae), Lyssomanes sp. (Salticidae), Misumenops spp. (Thomisidae) and Theridiidae with whitefly populations.

A higher whitefly attack (Figure 1) was observed in the second okra plantation, planted $50 \mathrm{~m}$ apart from the first, probably due to the fact that part of the whitefly population migrated from the first plantation, or that the plants were older and, consequently, a greater amount of time was available to increase insect population, or there was a higher proportion between natural enemies/whitefly nymphs in the first okra plantation. At the beginning of the first and second plantations, natural enemies were not detected, except for ladybirds in the first, indicating that these natural enemies were latent in nearby areas until okra plants infested with nymphs appeared. Hirano et al. (1995) reported that one of the major factors responsible for whitefly population dynamics seems to be temporal variations in the quantity of host plants in the area.

Although no significant effects of plant age, total rainfall and median temperature on whitefly population were observed, in October, when plants were 140 days old, there was a drastic decrease in the insect population, probably due to plant senescence or associated with rainy season (Figure 1). According to Legaspi et al. (1996a) and Stansly et al. (1997), whitefly population dynamics was apparently determined by environmental factors and crop phenology, and natural enemy population tended to increase at the end of the cultivar cycle. This leads to a reduction in plant quality, accompanied by decreases in insect pests with its natural enemy population. Horowitz (1986) observed in Sudan that heavy rains were usually followed by a drop in whitefly population levels.

Natural enemies, mainly the parasite Encarsia sp. and the predators Chrysoperla spp. and Coccinellidae are 

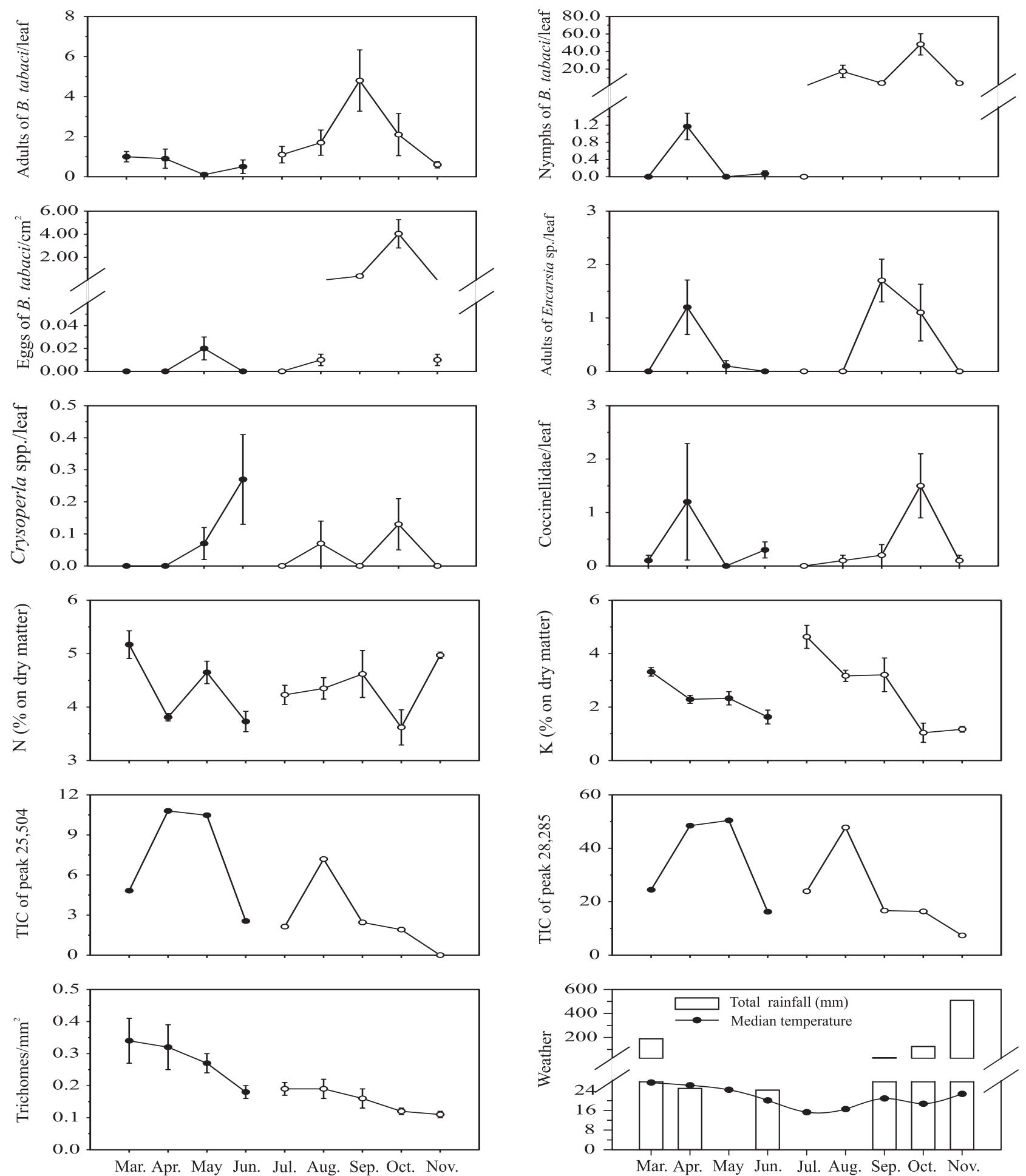

Figure 1. Fluctuations in populations of Bemisia tabaci, Encarsia sp., Chrysoperla spp. (adults + larvae) and Coccinellidae (adults + larvae), nitrogen and potassium content, total ion current (TIC) of peaks with retention times of 25,504 and 28,285 min and trichomes (adaxial + abaxial/2) of two okra plantations, $1(\bullet)$ and $2(\mathrm{O})$, total rainfall $(\mathrm{mm})$ and median temperature $\left({ }^{\circ} \mathrm{C}\right)$ in Abelmoschus esculentus crop. The symbols represent the average of 30 leaves for $B$. tabaci and Coccinellidae, ten leaves for Encarsia sp., three evaluations for the NK content and trichomes and one evaluation for the peaks, the rainfall accumulated and the average of the temperature of 30 days. Vertical bars indicate standard errors of the mean. 
probably responsible for a decrease in whitefly population. Possibly some of the whitefly nymphs found in August were parasited by Encarsia sp., since there was a reduction in the number of whitefly nymphs and an increase in the number of Encarsia sp. in September. These natural enemies have been used to control whitefly population in several plants (Legaspi et al., 1996a, 1996b; Liu \& Stansly, 1996a, 1996b) and, in some cases, a positive effect was obtained (Hoelmer et al., 1994; Heinz \& Nelson, 1996). Hooks et al. (1998) reported high populations of coccinellids and syrphids in zucchini plants infested with high populations of aphids and whiteflies. On the other hand, Hagler \& Naranjo (1994) observed that Hippodamia convergens Guérin-Menéville (Coleoptera: Coccinellidae) appeared to be capable of locating whitefly present in low density even at the beginning of the season.

Leaf $\mathrm{N}$ and $\mathrm{K}$ levels and leaf chemical composition were not correlated with whitefly population. A correlation between trichome density $(y=0.35-0.002 x$, $\left.\mathrm{R}^{2}=0.87, \mathrm{P}<0.05\right)$ and leaf $\mathrm{K}$ levels $(\mathrm{y}=4.07-0.02 \mathrm{x}$, $\left.\mathrm{R}^{2}=0.53, \mathrm{P}<0.05\right)$ was observed as plant age increased (Figure 1). Two peaks were observed in okra plants in both plantations. The first peak, with retention times of 25,504 min, was identified as palmitic acid with SI of $88 \%$, and the second, with $28,285 \mathrm{~min}$, was identified as $11,14,17$ eicosatrienoic methyl ester acid with SI of $83 \%$. Higher total ion current (TIC) for the peak 25,504 min were recorded for 46 and 76-day-old plants in the first and second plantations, respectively, and for the peak 28,285 min were recorded for 80-day-old plants in both plantations (Figure 1).

The 11,14,17 eicosatrienoic methyl ester acid, identified in the hexane extracts using the mass spectral data base, has not been reported for okra. However, palmitic acid was related in the seed oil content (28\%) of okra (Camciuc et al., 1998) as well as from the internal lipids of B. argentifolii adults (Buckner \& Hagen, 2003). Although these compounds were identified with a high SI, their identity should be confirmed by other methods. For this, it is necessary to isolate these compounds in large quantities and identify them through more precise spetroscopic methods.
A higher whitefly nymph density/leaf was recorded on the medium part (10.5 A) of the plant canopy, compared to the bottom (5.9 B) and apical (8.4 AB) regions. However, plant canopy and natural enemies did not affect the whitefly adults and eggs number. Higher density of non-glandular trichomes $/ \mathrm{mm}^{2}$ (100\% of trichomes) was observed in the apical $(0.21 \mathrm{~A})$ part than in the medium $(0.09 \mathrm{~B})$ and bottom $(0.10 \mathrm{AB})$ parts of A. esculentus, and in the abaxial $(0.30 \pm 0.04)$ than in the adaxial leaf surface $(0.08 \pm 0.01)$.

Although nutritional, chemical and morphological changes in plants have been reported to affect whitefly population in tomato, beans, and zucchini (Noortje \& Lindhout, 1992; Hooks et al., 1998; Leite et al., 1998), leaf $\mathrm{N}$ and $\mathrm{K}$, chemical compounds analyzed and trichomes were apparently not important in this study. The trichomes (\% non-glandular) found in okra were of low density and did not contain toxic compounds, which could affect oviposition and present antibiotic effects. This was expected because this okra cultivar has been selected for a long time to maximise productivity of fruits, which reduces the frequency of glandular trichomes and its resistance from attack by herbivore arthropods. The NK fertilization can affect the degree of attack from insects. An excess of $\mathrm{N}$ and deficiency in $\mathrm{K}$ have been reported to lead to higher accumulation of amino acids in plants and a higher degree of insect attack, such as whitefly (Marschner, 1995; Leite et al., 1998). The effect of leaf $\mathrm{N}$ and $\mathrm{K}$ levels in okra with whitefly was not detected due to the small variation of these nutrients in the leaves during the experimental period.

The whitefly oviposited preferentially in young leaves which are generally located on the apical parts, with the last stage nymphs customarily found in the bottom leaves (Leite et al., 1998). However, whitefly eggs and adult numbers were not found to be significantly correlated with position in the okra canopy, but higher number of nymphs was observed in the medium rather than in the bottom part. A plausible explanation for the nonoccurrence of oviposition preferentially on the apical leaves is that these leaves have more trichomes, which can make locomotion, feeding and oviposition of insects difficult (Dent, 1995), despite the absence of significant relationship between them. 
Hence, to reduce whitefly population it is necessary: to plant okra in a discontinuous (space and time) fashion without offering other host plants for this pest; to colonize, quickly, okra plantations with natural enemies (e.g. refuge crops and weedy margins), in order to achieve success on biological control; and to utilize insecticides, always selective, only when whitefly reached nominal thresholds.

\section{Conclusion}

1. Whitefly population dynamics in okra is affected by crop senescence, natural enemies and adult migration from nearby okra plants.

2. Total rainfall can reduce the whitefly population.

3. Trichomes non-glandular or low density is not important for reducing whitefly population.

\section{References}

BUCKNER, J.S.; HAGEN, M.M. Triacylglycerol and phospholipid fatty acids of the silverleaf whitefly: composition and biosynthesis. Archives of Insect Biochemistry and Physiology, v.53, p.66-79, 2003.

CAMCIUC, M.; DEPLAGNE, M.; VILAREM, G.; GASET, A. Okra-Abelmoschus esculentus L. (Moench.) a crop with economic potential for set aside acreage in France. Industrial Crops and Products, v.7, p.257-264, 1998.

DENT, D.R. Integrated pest management. London: Chapman and Hall, 1995. 356p.

FARIAS, A.R.N. Flutuação populacional de Aleurothrixus aepim em mandioca, em São Miguel das Matas, Bahia. Revista Brasileira da Mandioca, v.13, p.119-122, 1994.

FILGUEIRA, F.A.R. Novo manual de olericultura. Viçosa: UFV, 2000. 402p.

FISHPOOL, L.D.C.; BURBAN, C. Bemisia tabaci: the whitefly vector of African cassava mosaic geminivirus. Tropical Science, v.34, p.55-72, 1994.

HAGLER, J.R.; NARANJO, S.E. Qualitative survey of two coleopteran predators of Bemisia tabaci (Homoptera: Aleyrodidae) and Pectinophora gossypiella (Lepidoptera: Gelechiidae) using a multiple prey gut content ELISA. Environmental Entomology, v.23, p.193-197, 1994.

HEINZ, K.M.; NELSON, J.M. Interspecific interactions among natural enemies of Bemisia in an inundative biological control program. Biological Control, v.6, p.384-393, 1996.
HIRANO, K.; BUDIYANTO, E.; SWASTIKA, N.; FUJII, K. Population dynamics of the whitefly, Bemisia tabaci (Gennadius) (Homoptera: Aleyrodidae), in Java, Indonesia, with special reference to spatio-temporal changes in the quantify of food resources. Ecological Research, v.10, p.75-85, 1995.

HOELMER, K.A.; OSBORNE, L.S.; YOKOMI, R.K. Interactions of the whitefly predator Delphastus pusillus (Coleoptera: Coccinellidae) with parasitized sweetpotato whitefly (Homoptera: Aleyrodidae). Environmental Entomology, v.23, p.136-139, 1994.

HOOKS, C.R.R.; VALENZUELA, H.R.; DEFRANK, J. Incidence of pests and arthropod natural enemies in zucchini grown with living mulches. Agriculture, Ecosystems and Environment, v.69, p.217231, 1998.

HOROWITZ, A.R. Control strategy for the sweetpotato whitefly, Bemisia tabaci, late in the cotton-growing season. Phytoparasitica, v.21, p.281-291, 1993.

HOROWITZ, A.R. Population dynamics of Bemisia tabaci (Gennadius): with special emphasis on cotton fields. Agriculture, Ecosystems and Environment, v.17, p.37-47, 1986.

HOROWITZ, A.R.; PODOLER, H.; GERLING, D. Life table analysis of the tobaco whitefly Bemisia tabaci (Gennadius) in cotton fields in Israel. Acta Oecologica-Oecologia Applicata, v.5, p.221233, 1984.

JOSE, J.; USHA, R. Bhendi yellow vein mosaic disease in India is caused by association of a DNA beta satellite with a Begomovirus. Virology, v.305, p.310-317, 2003.

LEGASPI, J.C.; CORREA, J.A.; CARRUTHERS, R.I.; LEGASPI JUNIOR, B.C.; NORDLUND, D.A. Effect of short-term releases of Chrysoperla rufilabris (Neuroptera: Chrysopidae) against silverleaf whitefly (Homoptera: Aleyrodidae) in field cages. Journal of Entomological Science, v.31, p.102-111, 1996a.

LEGASPI, J.C.; NORDLUND, D.A.; LEGASPI JUNIOR, B.C. Tri-trophic interactions and predation rates in Chrysoperla spp. attacking the silverleaf whitefly. Southwestern Entomologist, v.21, p.33-42, 1996b.

LEITE, G.L.D.; PICANÇO, M.; ZANUNCIO, J.C.; GONRING, A.H.R. Effect of fertilization levels, age and canopy height of Lycopersicon spp. on attack rate of Bemisia tabaci (Homoptera: Aleyrodidae). Agronomia Lusitana, v.46, p.53-60, 1998.

LIU, T.X.; STANSLY, P.A. Morphology of Nephaspis oculatus and Delphastus pusillus (Coleoptera: Coccinellidae), predators of Bemisia argentifolii (Homoptera: Aleyrodidae). Proceedings of the Entomological Society of Washington, v.98, p.292-300, 1996a.

LIU, T.X.; STANSLY, P.A. Oviposition, development, and survivorship of Encarsia pergandiella (Hymenoptera: Aphelinidae) in four instars of Bemisia argentifolii (Homoptera: Aleyrodidae). Annals of the Entomological Society of America, v.89, p.96102, 1996b.

MARSCHNER, H. Mineral nutrition of higher plants. London: Academic Press, 1995. 889p. 
MIRANDA, M.M.M.; PICANÇO, M.; LEITE, G.L.D.; ZANUNCIO, J.C.; CLERCQ, P. Sampling and non-action levels for predators and parasitoids of virus vectors and leaf miners of tomato plants in Brazil. Mededelingen Faculteit Landbouwwetenschappen Universiteit Gent, v.63, 519-523, 1998.

NOORTJE, B.C.; LINDHOUT, P. Resistance in Lycopersicon hirsutum f. glabratum to the greenhouse whitefly (Trialeurodes vaporariorum) increases with plant age. Euphytica, v.64, p.189-195, 1992.
STANSLY, P.A.; SCHUSTER, D.J.; LIU, T.X. Apparent parasitism of Bemisia argentifolii (Homoptera: Aleyrodidae) by Aphelinidae (Hymenoptera) on vegetable crops and associated weeds in South Florida. Biological Control, v.9, p.49-57, 1997.

UMAHARAN, P.; PADIDAM, M.; PHELPS, R.H.; BEACHY, R.N.; FAUQUET, C.M. Distribution and diversity of geminiviruses in Trinidad and Tobago. Phytopathology, v.88, p.1262-1268, 1998.

Received on May 21, 2003 and accepted on September 3, 2004 